\title{
PERBANDINGAN KADAR AKRILAMIDA PADA MINYAK GORENG BEKAS SEBELUM DAN SESUDAH DIJERNIHKAN DENGAN KARBON AKTIF
}

\author{
${ }^{1}$ Neni Sri Gunarti \\ ${ }^{2}$ Lilis Tuslinah \\ ${ }^{3}$ Saeful Amin \\ ${ }^{1}$ Prodi Farmasi Universitas Buana Perjuangan Karawang, \\ neni.gunarti@ubpkarawang.ac.id \\ 2 Jurusan Farmasi STIKes BTH Tasikmalaya, lilistuslinah@yahoo.com \\ 3 Jurusan Farmasi STIKes BTH Tasikmalaya, saefulamin@yahoo.com
}

\begin{abstract}
ABSTRAK
Telah dilakukan analisis kadar akrilamida pada minyak goreng bekas sebelum dan sesudah dijernihkan dengan karbon aktif dengan menggunakan metode Kromatografi Cair Kinerja Tinggi ( KCKT ). Kondisi percobaan yang digunakan adalah sebagai berikut : campuran Asetonitril dan Dapar Fosfat pH 2,5 (5:95) sebagai fase gerak, ZORBAX Eclipse XDB-C18 ( 3x150 mm, 3,5 :m), laju alir 0.5 ml/menit, suhu $25^{\circ} \mathrm{C}$, volume sampel yang disuntikkan $20: 1$ dan panjang gelombang $210 \mathrm{~nm}$. Metode ini memiliki parameter validasi Kecermatan 100,873\%, koefisien variasi untuk waktu retensi dan AUC masing-masing 0,361 dan 1,995\%. Metode ini memiliki Koefisien Korelasi ( $\mathrm{r}$ ) 0,998, nilai koefisien variasi garis regresi $\left(\mathrm{Vx}_{0}\right)$ 4,854\%, batas deteksi 0,156 ppm dan batas kuantitasi 0,404 ppm. Penjernihan minyak goreng bekas dilakukan dengan 5 gram karbon aktif pada suhu $95^{\circ} \mathrm{C}$ selama 80 menit. Akrilamida diisolasi dari minyak goreng bekas dengan cara ekstraksi menggunakan diklorometana dan fase gerak lalu dilakukan penguapan diklorometana selama 5 jam. Hasil pengujian menunjukkan kadar akrilamida minyak goreng bekas sebelum dan sesudah penjernihan masing masing adalah 0,147 ppm menjadi 1,079 ppm dengan peningkatan kadar akrilamida lebih dari $100 \%$ dari kadar sebelum dijernihkan.
\end{abstract}

Kata Kunci : Akrilamida, Penjernihan, KCKT, Karbon aktif, validasi metode 


\begin{abstract}
Acrylamide had been analized from frying oil after and before bleaching with activied carbon use High Performance Liquid Chromatography (HPLC) method. Under following conditions : a mixture of phosphoric acid solution $\mathrm{pH} 2,5$ and acetonitrile (95:5) as mobile phase, a ZORBAX Eclipse coloum XDB-C18 ( $3 \times 150 \mathrm{~mm}, 3,5$ :m), flow rate $0.5 \mathrm{ml} / \mathrm{menit}$, at $25^{\circ} \mathrm{C}$, a UV Detector at $210 \mathrm{~nm}$. The method gave a percentage recovery $100,873 \%$, relative standard deviation (RSD) for retention time and AUC respectively 0,361 and 1,995\%, a method has correlation coefficient (r) 0,998 , regression variation coefficient $\left(\mathrm{Vx}_{0}\right) 4,854 \%$, limit of detection $0,156 \mathrm{ppm}$ and limit of quantitation 0,404 ppm. Frying oil bleaching has applied with extraction use diclorometahne and mobile fase, and then dicloromethane evaporated for 5 hours. A result has shown acrylamide consentration before and after frying oil bleaching respectively 0,147 to $1,075 \mathrm{ppm}$ with increasing consentration more than $100 \%$ from before bleaching.
\end{abstract}

Keywords : Acrylamide, Bleaching, HPLC, Actived Carbon, Validation method.

\title{
PENDAHULUAN
}

Minyak goreng adalah hasil akhir (refined oils) dari sebuah proses pemurnian minyak nabati (golongan yang biasa dimakan) dan terdiri dari beragam jenis senyawa trigliserida. Minyak dapat digunakan sebagai medium penggoreng bahan pangan. Dalam penggorengan, minyak goreng berfungsi sebagai medium penghantar panas, menambah rasa gurih, menambah nilai gizi dan kalori dalam bahan pangan. Tetapi pemanasan minyak secara berulang-ulang pada suhu tinggi dan waktu yang cukup lama, akan menghasilkan senyawa polimer yang berbentuk padat dalam minyak. Kerusakan minyak selama proses penggorengan akan mempengaruhi mutu dan nilai gizi dari bahan pangan yang digoreng (Ketaren, 1986).

Minyak yang dipanaskan akan menghasilkan aldehid akrilat atau akrolein yang memiliki bau seperti lemak terbakar dan ditandai dengan asap putih. Akrolein merupakan salah satu senyawa pembentuk akrilamida selain terbentuk dari asam amino langsung dan dari dehidrasi atau dekarboksilasi beberapa asam organik tertentu. Akrolein selanjutnya dapat mengalami oksidasi membentuk asam akrilat atau membentuk senyawa antara berupa radikal akrilat. Kedua senyawa tersebut, dengan adanya sumber nitrogen (umumnya gugus amina dari asam amino) dan kondisi yang 
sesuai, dapat membentuk akrilamida. Semakin tinggi suhu dan lama pemanasan minyak goreng, semakin tinggi kadar akrilamida yang ditemukan (Napitupulu,2008).

International Agency for Research on Cancer (IARC), U.S. Environmental Protection Agency (EPA), Food and Drug Administration (FDA), serta The National Toxicology Program telah mengklasifikasikan akrilamida sebagai senyawa yang menyebabkan kanker atau berpotensi sebagai karsinogenik pada manusia (grup 2A). Berdasarkan studi hewan coba, akrilamida diketahui berpotensi menyebabkan kerusakan sel-sel saraf dan gangguan reproduksi pada hewan coba serta pemberian akrilamida dalam jangka panjang dapat menyebabkan tumor.

Penggunaan adsoben telah banyak digunakan untuk meningkatkan kualitas minyak goreng bekas. Karbon aktif telah terbukti dapat meningkatkan kualitas minyak goreng bekas (Rosita.et.al,2008). Arang tempurung kelapa merupakan salah satu sumber karbon aktif yang dapat digunakan. Namun belum diketahui pengaruhnya terhadap kadar akrilamida hasil penjernihan dengan karbon aktif. Maka dilakukan penelitian untuk mengetahui kadar akrilamida dari minyak sebelum dan sesudah dijernihkan dengan karbon aktif dengan metode Kromatografi Cair Kinerja Tinggi (KCKT).

\section{METODE PENELITIAN}

Bahan dan Alat

Bahan penelitian yang digunakan adalah minyak goreng bekas, Karbon aktif dari PT.Brataco, Asetonitril pro. HPLC dari J.T. Baker, Asam Fosfat dari 85\% pro.analisis dari PT.Merck, Dinatrium hidrogen fosfat dari PT. Merck, diklorometana dari PT.MERCK, Etanol dari PT.Brataco, Akrilamida SIGMA A3553, Aqua Bidestilata Steril dari PT.IKA.

Alat penelitian yang digunakan adalah Spektofotometer UV-Vis SHIMADZU 1240, HPLC Agilent Technologies 1120 Compact LC dilengkapi dengan detector UVVisible, kolom ZORBAX Eclipse XDB-C18 ( 3x150 mm, 3,5 :m), syringe, filter eluen dan sampel, membrane filter Whatman Nylon 0,2 :m, vial, penangas air 0-100 $\mathrm{C}$, sentrifuga, $\mathrm{pH}-\mathrm{Meter}$, termometer, heater, magnetic stirrer, timbangan analitis Metler Toledo, Vortex Mixer, dan alat-alat gelas yang umum digunakan dalam laboratorium analisis. 
Prosedur Penelitian

\section{Penyiapan sampel}

Sampel minyak goreng bekas rumah tangga dimasukkan ke dalam botol coklat. Dibagi dua untuk yang akan dilakukan penjernihan dan tidak dilakukan penjernihan.

\section{Penjernihan dengan Karbon Aktif}

Ditimbang sampel $250 \mathrm{~g}$ minyak goreng bekas ke dalam beaker glass berukuran $500 \mathrm{ml}$, ditimbang 5 gram karbon aktif dimasukkan ke dalam beaker glass yang berisi minyak lalu aduk dengan magnetic stirrer selama 80 menit pada suhu $95{ }^{0} \mathrm{C}$. Minyak tersebut disaring setelah itu siap dianalisis.

\section{Penyiapan fase gerak dan Baku Pembanding}

Fase gerak (eluen) yang digunakan adalah dapar fosfat $\mathrm{pH}$ 2,5-asetonitril dengan perbandingan 95:5. Pembuatan dapar fosfat adalah dengan cara melarutkan 6.9 $\mathrm{g} \mathrm{Na}_{2} \mathrm{HPO}_{4}$ dengan aqua bidestilata steril, tambahkan asam fosfat hingga $\mathrm{pH}$ mencapai 2,5 dengan pH-Meter lalu di add dengan aqua bidestilata steril sampai $1000 \mathrm{ml}$. Selanjutnya dapar disaring dengan filter eluen, lalu buat eluen dengan mencampur 950 $\mathrm{ml}$ dapar fosfat $\mathrm{pH}$ 2,5 dan $50 \mathrm{ml}$ asetonitril sehingga perbandingannya 95:5.

Larutan induk akrilamida dibuat $10 \mathrm{ppm}$ dengan cara melarutkan $1 \mathrm{mg}$ akrilamida dengan fase gerak hingga $100 \mathrm{ml}$.

Larutan standar eksternal yang dibuat adalah 0,$5 ; 1 ; 1,5 ; 2 ; 2,5$ ppm dalam sampel yang dianalisis.

\section{Penentuan Kesesuaian Sistem KCKT}

Kondisi percobaan dipilih pada kolom ZORBAX Eclipse XDB-C18 ( 3x150 $\mathrm{mm}, 3,5 \mu \mathrm{m}$ ), laju alir $0.5 \mathrm{ml} / \mathrm{menit}$, suhu $25^{\circ} \mathrm{C}$, volume sampel yang disuntikkan $20 \mu \mathrm{l}$ dan panjang gelombang $210 \mathrm{~nm}$. Penentuan kondisi optimum mengacu pada beberapa parameter kualitas pemisahan, yaitu waktu pemisahan $\left(t_{R}\right)$, faktor kapasitas $\left(k^{\prime}\right)$ dan efisiensi kolom (N). Persyaratan kesesuaian sistem kromatografi, yaitu waktu retensi (5 menit $<\mathrm{t}_{\mathrm{R}}<10$ menit), faktor kapasitas $\left(1 \leq k^{\prime} \leq 10\right)$ dan jumlah pelat teoritik $(N \geq 10.000)$. 


\section{Validasi Metode}

\section{Kelinieran}

Larutan baku eksternal 0,$5 ; 1 ; 1,5 ; 2 ; 2,5$ ppm ppm disuntikkan sebanyak 20:1 ke dalam kolom pada kondisi yang telah ditentukan. Dibuat kurva antara konsentrasi (sumbu $\mathrm{x}$ ) terhadap luas puncak (sumbu y). Diperoleh persamaan regresi $\mathrm{y}=\mathrm{bx}+\mathrm{a}$, koefisien korelasi (r) dan determinasi $\left(\mathrm{r}^{2}\right)$, nilainya harus mendekati 1.

\section{Keseksamaan ( Presision )}

Larutan baku eksternal berdasarkan Batas Deteksinya sebagai konsentrasi $80 \%$. Sehingga analit yang diukur yaitu yang memiliki konsentrasi 80, 100 dan $120 \%$, selanjutnya disuntikkan sebanyak 20:1 ke dalam kolom pada kondisi yang telah ditentukan,diulang sebanyak 6 kali. Diperoleh Simpangan Baku Relatif (SBR) nilai persyaratannya kurang dari $2 \%$.

\section{Kecermatan ( Recovery )}

Kecermatan dilakukan dengan spiked method dengan cara membuat larutan simulasi 0 (blangko); 0,$5 ; 1 ; 1,5 ; 2 ; 2,5$ ppm akrilamida dalam sampel. Disuntikkan sebanyak 20:1 ke dalam kolom pada kondisi yang telah ditentukan dan didapat persen recovery.

\section{Penetapan kadar akrilamida dalam sampel minyak}

Ditimbang 15 g sampel minyak yang mengandung larutan standar eksternal, kemudian dilarutkan dalam $60 \mathrm{ml}$ diklorometana, ditambahkan $3 \mathrm{ml}$ etanol, kemudian dikocok dengan laboratory shacker pada kecepatan 200 RPM selama 10 menit. Larutan tersebut disaring, filtrat ditampung dan residu dicuci dengan diklorometana sebanyak 2 x $5 \mathrm{ml}$ dan disaring kembali, kemudian filtrat digabung dan ditambahkan $25 \mathrm{ml}$ fase gerak yang digunakan. Diklorometana dan etanol diuapkan di atas penangas air pada suhu $80^{\circ} \mathrm{C}$ selama 5 jam, kemudian disentrifugasi dengan kecepatan 8000 RPM selama 15 menit, diambil lapisan fase gerak lalu dimasukkan ke dalam labu ukur $50 \mathrm{ml}$ dan tambahkan fase gerak yang dugunakan dan digenapkan sampai batas. Larutan sampel disaring dengan penyaring sampel Whatman $0.45 \mu \mathrm{m}$. Larutan sampel disuntikkan sebanyak $20 \mu L$ ke dalam kolom kemudian dicatat luas puncaknya.

Kadar akrilamida sampel berdasarkan rumus regresi yang diperoleh dari pengukuran larutan standar eksternal dimana nilai $\mathrm{y}=0$ sehingga didapat nilai $\mathrm{x}$ dan dikali 2 kali pengenceran yang merupakan kadar sampel yang sebenarnya. 


\section{PEMBAHASAN}

Hasil spektrofotometri UV-Visible menunjukkan serapan maksimum Akrilamida $197,5 \mathrm{~nm}$ dalam eluen asetonitril : buffer fosfat $\mathrm{pH}$ 2,5 sebagai pelarutnya. Pengukuran Akrilamida dilakukan dengan menggunakan metode Kromatografi Cair Kinerja Tinggi. Metode keromatografi cair kinerja tinggi dipilih karena waktu analisisnya cepat, cara kerjanya sederhana, dan relatif murah. Detektor yang digunakan pada penelitian ini adalah detektor UV-VIS. Akrilamida mempunyai gugus kromofor (gugus yang mempunyai ikatan rangkap berkonjugasi) dan gugus auksokrom (gugus yang memiliki pasangan elektron bebas) sehingga dapat terjadi transisi elektronik walaupun lemah. Panjang gelombang yang digunakan untuk mendeteksi akrilamida dalam sampel tidak menggunakan panjang gelombang 197,5 nm namun yang digunakan adalah $210 \mathrm{~nm}$. Asetonitril memiliki serapan $200 \mathrm{~nm}$, sehingga dibutuhkan panjang gelombang dimana zat pengotor tidak ikut terserap sehingga dipilih panjang gelombang $210 \mathrm{~nm}$.

Minyak goreng dapat membentuk akrilamida karena salah satunya terdapat akrolein hasil degradasi minyak, sehingga dengan adanya sumber nitrogen yang ada dalam makanan dapat membentuk akrilamida yang larut dalam air. Selain dari akrolein pembentukan akrilamida juga berasal dari asam amino yang memiliki struktur mirip akrilamida seperti metionin,asparagin dan juga gula pereduksi yang membentuk akrilamida pada suhu diatas $120^{\circ} \mathrm{C}$.

Proses ekstraksi akrilamida dalam minyak menggunakan diklorometana untuk melarutkan zat yang nonpolar, untuk meningkatkan kelarutan akrilamida dalam diklorometana maka ditambahkan etanol. Proses ekstraksi tidak dilakukan secara langsung dengan ekstraksi cair-cair menggunakan diklorometana dan air karena akrilamida tidak terekstraksi seluruhnya dalam air. Oleh karena itu ekstraksi dilakukan dengan cara penambahan diklorometana dan air selanjutnya diklorometana diuapkan. Cara ini telah terbukti meningkatkan perolehan kembali (97\%) dibandingkan dengan ekstraksi cair-cair secara langsung (60\%) (Harahap,2005). Dengan adanya penguapan diklorometana akrilamida yang ada dalam fase diklorometana akan terlarut ke dalam fase air tanpa terbawanya senyawa organic yang tidak larut dalam pelarut polar namun proses penguapannya memerlukan waktu 4-5 jam.

Kromatografi Cair Kinerja Tinggi yang digunakan adalah jenis elusi isokratik, artinya pencampuran eluen dilakukan di awal sebelum dimasukkan ke botol eluen. Cara 
ini memungkinkan kurangnya ketepatan perbandingan eluen dan kemungkinan penguapan asetonitril tinggi sehingga mempengaruhi pada komposisi eluen. Eluen yang digunakan adalah asetonitril dan dapar fosfat $\mathrm{pH}$ 2,5 dengan perbandingan 5:95. Akrilamida bersifat polar sehingga pemilihan fase geraknya polar sedangkan fase diamnya dipilih kolom $\mathrm{C} 18$ yang bersifat nonpolar. Maka dari itu proses kromatografi yang digunakan adalah fase terbalik.

Kondisi percobaan dipilih pada kolom kolom ZORBAX Eclipse XDB-C18 $3 \times 150 \mathrm{~mm}, 3,5 \mathrm{:m}$ ), laju alir $0.5 \mathrm{ml} / \mathrm{menit}$, suhu $25^{\circ} \mathrm{C}$, volume sampel yang disuntikkan 20 :1 dan panjang gelombang $210 \mathrm{~nm}$. Penentuan Uji Kesesuaian sistem menghasilkan parameter yang memenuhi persyaratan yaitu waktu retensi akrilamida 8,587 menit dan faktor selektifitas 1,139 .

Kelinieran ditentukan dengan standar eksternal yaitu dimulai dari blangko; 0,5; $1 ; 1,5 ; 2 ; 2,5$ ppm. Cara ini dipilih karena kadar analit dalam sampel kecil dan menghindari hilangnya analit yang berlebihan selama preparasi sampel. Selain itu cara ini juga dapat sekaligus digunakan untuk uji kecermatan (recovery).

Persamaan regresi yang didapat dari standar eksternal dari minyak goreng bekas sebelum penjernihan adalah $\mathrm{y}=500.138,571 \mathrm{x}+36.745,619$ dengan koefisien korelasi (r) 0,998. Nilai ini sudah memenuhi persyaratan artinya kadar analit dengan menggunakan kurva kalibrasi tersebut terjamin kebenarannya. Nilai koefisien variasi garis regresi 4,854\% artinya memenuhi persyaratan (kurang dari 5\%).

Berdasarkan hasil perhitungan batas deteksi dan batas kuantitasi akrilamida masing-masing adalah 0,156 dan 0,404 ppm. Hal ini berarti batas konsentrasi minimal akrilamida yang dapat dikuantisasi dengan baik untuk uji keseksamaan dan kecermatan adalah 0,404 ppm. Dari persamaan regresi maka dapat dihitung kadar sampel pada saat $\mathrm{y}=0$ kadar akrilamida dalam minyak goreng sebelum penjernihan dengan karbon aktif adalah 0,073 ppm, dikarenakan dilakukan pengenceran dua kali sehingga konsentrasi realnya menjadi 0,147 ppm. Sedangkan kadar akrilamida dalam minyak goreng bekas setelah penjernihan adalah 0,539 ppm dikali dua kali pengenceran menjadi 1,079 ppm.

Uji kecermatan dilakukan dengan cara spiked method sekaligus untuk menentukan kelinieran. Perolehan kembali (recovery) didapat dari hasil pengukuran baku eksternal 0,$5 ; 1 ; 1,5 ; 2 ; 2,5$ ppm. Hasil perolehan kembali (recovery) dapat dilihat pada tabel 1 
Tabel 1 Hasil perolehan kembali (\% recovery)

\begin{tabular}{|ccccc|}
\hline ppm, Xi & AUC, Yi & Kons.persamaan & Konsentrasi real & \% Recovery \\
\hline $\mathbf{0 , 5}$ & 329.712 & 0,543 & 1,086 & 108,626 \\
\hline $\mathbf{1}$ & 545.763 & 0,990 & 1,980 & 98,988 \\
\hline $\mathbf{1 , 5}$ & 755.695 & 1,424 & 2,848 & 94,931 \\
\hline $\mathbf{2}$ & 1.039 .063 & 2,010 & 4,020 & 100,496 \\
\hline $\mathbf{2 , 5}$ & 1.292 .084 & 2,533 & 5,066 & 101,324 \\
\hline & & & Rata-rata & 100,873 \\
\hline
\end{tabular}

Persen perolehan kembali yang diperbolehkan untuk analit 1 ppm sampai 100 ppb adalah 80-110 \% (Harmita,2004). Maka berdasarkan persyaratan tersebut persen perolehan kembali (\% recovery) telah memenuhi persyaratan. Kecermatan hasil analis sangat tergantung kepada sebaran galat sistematik di dalam keseluruhan tahapan analisis. Oleh karena itu untuk mencapai kecermatan yang tinggi hanya dapat dilakukan dengan cara mengurangi galat sistematik tersebut seperti menggunakan peralatan yang telah dikalibrasi, menggunakan pereaksi dan pelarut yang baik, pengontrolan suhu, dan pelaksanaannya yang cermat, taat asas sesuai prosedur (Harmita,2004).

Tabel 2 Hasil Pengukuran Keterulangan Sistem KCKT

\begin{tabular}{|ccr|}
\hline No & Waktu Retensi & \multicolumn{1}{l|}{ AUC } \\
\hline $\mathbf{1}$ & 9,903 & 902.799 \\
\hline $\mathbf{2}$ & 9,930 & 894.863 \\
\hline $\mathbf{3}$ & 9,950 & 871.939 \\
\hline $\mathbf{4}$ & 9,977 & 868.977 \\
\hline $\mathbf{5}$ & 9,980 & 875.293 \\
\hline $\mathbf{6}$ & 10,000 & 855.417 \\
\hline RT & $\mathbf{9 , 9 5 7}$ & $\mathbf{8 7 8 . 2 1 5}$ \\
\hline SD & $\mathbf{0 , 0 3 6}$ & $\mathbf{1 7 . 5 1 9}$ \\
\hline KV & $\mathbf{0 , 3 6 1 \%}$ & $\mathbf{1 , 9 9 5} \%$ \\
\hline
\end{tabular}


Hasil pengukuran menunjukkan koefisien variasi untuk waktu retensi dan AUC masing-masing adalah 0,361 dan $1,995 \%$. Nilai tersebut memenuhi persyaratan Koefisien Variasi $(\mathrm{KV})$ berdasarkan ICH yaitu $\leq 2 \%$. Kadar akrilamida dalam minyak goreng bekas sebelum dan setelah penjernihan mengalami peningkatan dari 0,147 ppm menjadi 1,079 ppm. Nilai ini menunjukkan adanya peningkatan kadar akrilamida 0,932 ppm. Peningkatan kadar akrilamida ini dapat dikarenakan proses otooksidasi minyak akibat pemanasan pada proses penjernihan dengan karbon aktif. Selain itu proses otooksidasi terjadi lebih cepat pada minyak yang dipucatkan dengan menggunakan arang aktif (activated carbon) (Ketaren,1985). Proses oksidasi minyak menghasilkan gliserol dan asam lemak. Hasil oksidasi zat tersebut membentuk akrolrin selanjutnya menjadi asam akrilat yang kedua-duanya merupakan precursor pembentuk akrilamida. Pembentukan akrilamida sangat tergantung dengan suhu dan lamanya pemanasan. Makin tinggi suhu dan lama pemanasan makin tinggi akdar akrilamida yang terbentuk (Napitupulu,2006). Meskipun penggunaan karbon aktif sebagai penjernih minyak goreng bekas telah terbukti mampu meningkatkan mutu minyak berdasarkan SNI namun disisi lain meningkatkan kadar akrilamida sehingga tidak layak untuk dikonsumsi kembali karena sifat karsinogeniknya.

\section{PENUTUP}

\section{Simpulan}

Penentuan kadar akrilamida dalam minyak goreng bekas menggunakan metode kromatografi cair kinerja tinggi dengan kondisi percobaan dipilih pada kolom kolom ZORBAX Eclipse XDB-C18 ( $3 \times 150 \mathrm{~mm}, 3,5 \mu \mathrm{m}$ ), laju alir 0,5 ml/menit, suhu $25^{\circ} \mathrm{C}$, volume sampel yang disuntikkan $20 \mu \mathrm{l}$ dan panjang gelombang $210 \mathrm{~nm}$. Metode ini memiliki parameter validasi kelinieran, kecermatan dan keterulangan yang memenuhi syarat. Kadar akrilamida dalam minyak goreng bekas sebelum dan setelah penjernihan mengalami peningkatan 0,932 ppm. Peningkatan kadar akrilamida ini dapat dikarenakan proses otooksidasi minyak akibat pemanasan pada proses penjernihan dengan karbon aktif.

\section{Saran}

Disarankan untuk melakukan analisis kadar akrilamida dalam sampel minyak goreng bekas yang telah dijernihkan dengan adsorben lain selain karbon aktif . 


\section{DAFTAR PUSTAKA}

Ketaren, S. 1986. Pengantar Teknologi Minyak dan Lemak Pangan, Edisi 1. Jakarta: UI Press; p. 45-70

Napitupulu, Toga. 2008. Pengaruh Suhu dan Lama Pemanasan terhadap Pembentukan Akrilamida pada Pembuatan Minyak Kelapa dengan Cara Panas [Skripsi]. Bandung: Program Studi Sains dan Teknologi Farmasi ITB

Rosita, Alinda.et.al. 2007. Peningkatan Kualitas Minyak Goreng Bekas dari KFC dengan Menggunakan Adsorben Karbon Aktif [Makalah Seminar]. Semarang: UNDIP; p.3

Harahap, Yardiana, 2005. Optimasi Penetapan Kadar Akrilamida yang Ditambahkan ke dalam Keripik Kentang Simulasi Secara Kromatografi Cair Kinerja Tnggi, Majalah Ilmu Kefarmasian, Volume II No 3 : 154-163

Harmita. 2004. Petunjuk Pelaksanaan Validasi Metode dan Cara Perhitungannya. Majalah Ilmu Kefarmasian, Vol. I, No.3 : 117 